\title{
MICROPOTAMIA, GEN.N. OF NEOTROPICAL MUSCIDAE (DIPTERA, AZELIINAE), WITH COMMENTS ON ALLIED AZELIINI GENERA ${ }^{1}$
}

\author{
Claudio José Barros de Carvalho ${ }^{2}$
}

\begin{abstract}
A new genus, Micropotamia, is erected for Phaonia minuscula Albuquerque, 1955 [type-species of the genus], Phaonia cilitibia Albuquerque, 1955 and Azelia amazonica Albuquerque \& Lopes, 1982. A key to these three species is given. The female of Micropotamia amazonica is described for the first time, from Roraima. Some character-states of phylogenetic importance and affinities with world Azeliini genera are discussed. Megophyra Emden, 1965 and Potamia Robineau-Desvoidy, 1830 are considered to be most closely related to Micropotamia, gen.n.

KEY WORDS. Micropotamia, Muscidae, Azeliini, phylogenetic relationships
\end{abstract}

ALBUQUERQUE (1955) described two species of Phaonia Robineau-Desvoidy, 1830, from Brazil (Rio de Janeiro, Minas Gerais and Mato Grosso do Sul). This genus is now recognized as a large paraphyletic assemblage (HENNIG, 1965; SKIDMORE, 1985; HUCKETT \& VOCKEROTH, 1987; CARVALHO, 1989b; 1993), as it is based on the presence of a "calcar" on the hind tibia, a ground-plan character-state of the Muscidae and consequently plesiomorphic for the family.

ALBUQUERQUE \& LOPES (1982) and CARVALHO (1983) transferred these two species to Azelia Robineau-Desvoidy, 1830. ALBUQUERQUE \& LOPES, 1982 also described Azelia amazonica from Amazonas, Brazil. It is now realized that these species do not belong to Azelia because they lack hind coxal setulae, a synapomorphy of the Azelia-group of genera. In this paper, a new genus is proposed for these Brazilian species.

The following acronyms are used for the location of material: DZUP Coleção Pe. Jesus Santiago Moure, Departamento de Zoologia da Universidade Federal do Paraná; INPA - Instituto Nacional de Pesquisas da Amazonia; MNRJ - Museu Nacional do Rio de Janeiro. For terminology see CARVALHO (1989a).

1) Contribuição número 768 do Departamento de Zoologia, Universidade Federal do Paraná.

2) Departamento de Zoologia, Universidade Federal do Paraná, Caixa Postal 19020, 81531-970 Curitiba, Paraná, Brasil. CNPq fellow. 


\section{Micropotamia, gen.n.}

Type-species: Phaonia minuscula Albuquerque, 1955.

Diagnosis. Micropotamia, gen.n. can be distinguished from other muscid genera by the following combination of character-states:

Male holoptic, eyes with normal pubescent; female dichoptic. Parafacial very slender, in both sexes, strongly tapering downwards. Arista pubescent, with hairs shorter than basal aristal width. Gena with a strong upcurved bristle. Dc $2: 3$; presutural acr developed; pra short, slightly longer than adjacent ground-setulae. Disc of notopleuron bare. Anepimeron bare. Ktps 1:2, the lower one weak. Metaspiracle small in both sexes, smaller than knob halteres, bare on margins. All wing veins bare, except costa. Subcosta smoothly curved in apical part (ALBUQUERQUE, 1955: Fig. 2). Mid femur with a preapical anterior bristle. Mid tibia with two median posterior bristles. Hind coxa bare on posterior apical margin. Hind tibia with strong calcar bristle at apical third. First abdominal sternite bare. Male: distiphallus with apical part of juxta spinulose (ALBUQUERQUE, 1955: Figs 3, 5, 6, 10, 12). Female: head with proclinate orbitals; interfrontal setae absent, but frontal plate with several setulae. Ovipositor (Figs 1, 2); tergite 6 hook-shape; sternite 8 developed; cerci long, reaching beyond hypoproct; 3 spermathecae.

Etymology. The generic name refers to small size of the species of this genus, contrasts with Holarctic and Neotropical species of true Potamia Robineau-Desvoidy, 1830.

Species included and geographic distribution. Micropotamia is erected for the Neotropical species previously placed in Azelia (except to Azelia neotropica Snyder, 1957). The new genus is known only from Brazil: $M$. minuscula (Albuquerque, 1955), comb.n., from Minas Gerais, Rio de Janeiro and São Paulo; M. cilitibia (Albuquerque, 1955), comb. n., from Mato Grosso do Sul, Rio de Janeiro and Rio Grande do Sul; and M. amazonica (Albuquerque \& Lopes, 1982), comb.n., from Roraima and Amazonas.

Relationships. Micropotamia belongs to the Azeliini (sensu CARVALHO, 1989b) on the basis of two character-states: a proclinate orbital in female, and subcosta smooth. The former character-state is in the ground-plan of the Muscidae (HENNIG, 1965). The second character is probably in the ground plan of Muscoidea (sensu MCALPINE, 1989), as it is found in the Fanniidae, Scathophagidae and the basal lineage of the Anthomyiidae (e.g. in Coenosopsia Malloch, 1924, but not in Phaonantho Albuquerque, 1957), the family proposed as the sister-group of the Muscidae (MICHELSEN, 1991).

However, there is some evidence that the Azeliini, a small muscid tribe with few genera and worldwide distribution, is a monophyletic group. The most striking character is the configuration of the male distiphallus, with juxta spinulose.

There is no published phylogenetic hypothesis for intergeneric 


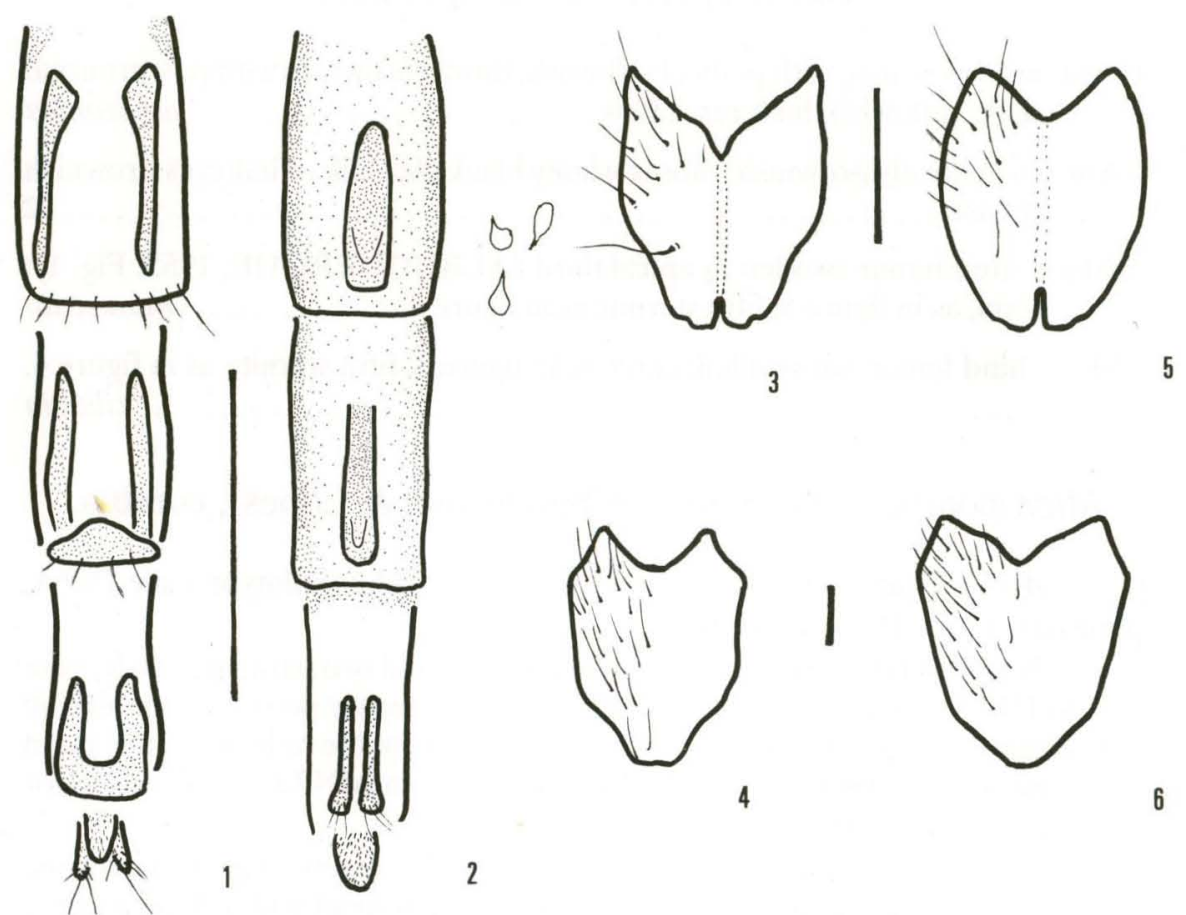

Figs. 1-6. Micropotamia amazonica, comb.n. female. (1) Ovipositor, dorsal view; (2) ovipositor, ventral view and spermathecae. (3-4) M. cilitibia (Albuquerque), male; (3) cerci, posterior view; (4) fifth sternite, posterior view. (5-6) M. minuscula (Albuquerque), male; (5) cerci, posterior view; (6) fifth sternite, posterior view. Figures $1-2$ scale $=1 \mathrm{~mm}$, figures $3-6$ scale $=0.1 \mathrm{~mm}$.

relationships in Azeliini, but MICHELSEN (1978) listed several characters which are of phylogenetic importance to his Hydrotaeini (now Azeliini). Most Azeliini genera have upwardly-curved bristles on the genae, and this may be a ground-plan of the Muscidae. Micropotamia species have a strong upcurved bristle on the gena, probably a more derived character-state of the upwardly-directed genal bristles just mentioned. These strong bristles are also found in two closely related Azeliini genera, Megophyra Emdem, 1965 with 8 species, known only from East Asia (SHINONAGA \& KANO, 1971; PONT, 1977, 1986; FAN, 1992) and Potamia Robineau-Desvoidy, with 5 valid species, widespread in the Holarctic (HUCKETT, 1965; PONT, 1977, 1986), but only two in South America (CARVALHO, 1981). Megophyra shares an apomorphous character-state with Micropotamia: the absence of interfrontal setae in the female. The subgenus Hydrotaeoides Skidmore, 1985, of Hydrotaea Robineau-Desvoidy, 1830 comprises species with strong upcurved genal bristle, but has cruciate interfrontal setae in the female. 


\section{Key to species of Micropotamia}

1. Antenna brownish, with pedicel yellowish; thorax brownish with postpronotal angle yellowish; halteres yellow ................... amazonica

- Antenna entirely brownish; thorax wholly blackish; stalk of halteres brownish

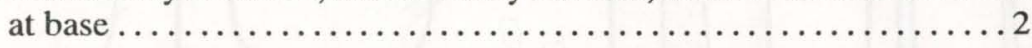

2. Male: hind femur swollen in apical third (ALBUQUERQUE, 1955: Fig. 1); cerci, as in figure 5; fifth sternite as in figure 6 ............minuscula

- Male: hind femur not swollen; cerci, as in figure 3; fifth sternite as in figure 4. cilitibia

\section{Micropotamia amazonica (Albuquerque \& Lopes), comb.n.}

Azelia amazonica Albuquerque \& Lopes, 1982:2 (holotype male INPA, paratypes males INPA/MNRJ).

Notes on type-material. The holotype male and two paratypes male were sent to INPA by post and were found to be almost tottaly destroyed on arrival: only fragments now exist, but the dissected genitalia of the holotype male are in glycerina in a microvial. The two male paratypes in MNRJ are also in poor condition, without abdomen and hind legs.

Description. Female. Head. Frons relatively narrow, slightly narrowing from vertex to lunula, measured across frons 0.31 of head-width. Upper inner eye-facets not enlarged. Parafacial, occiput and genae grey pruinose. Fronto-orbital plates and parafacial very slender, at narrowest point the former about 1/2 diameter of anterior ocellus. Antenna brownish, with pedicel yellowish. Frontal vitta blackish, reddish at lunula. 4 pairs of frontals, 3 pairs of orbitals with 2 proclinate and 1 reclinate on one side but 1 proclinate and 2 reclinate on the other side. Genae slender, the depth below lowest eye-margin subequal to diameter of anterior ocellus. Proboscis short; palpi rather clavate to tips. Thorax. Ground-colour brownish with sparce grey pruinosity; postpronotal angle and anterior spiracle distinctly yellowish. Mesonotum with short and scattered ground- setulae. Dc 2:3; prst acr in four rows; 2 postpronotals; 1 prst sa; 1 prst and 2 post ia, anterior post seta stronger. 1 st ntp subequal to $2 \mathrm{nd}$. Scutellum with a strong apical and subbasal lateral pair of bristles; basal pair weak. Seven anepisternal setae. Prosternum shining, undusted. 2 proepisternal setae and 1 proepimeral. Posterior spiracle brown. Wing clear, with a well-developed anal angle; veins pale brown. $\mathrm{R}_{4+5}$ and $\mathrm{M}_{1+2}$ parallel at apex. Calypters whitish. Halteres yellow. Legs. Dark, with fore knee and tibia yellowish. Fore femur with a row of $10 \mathrm{PV}$ bristles; with a complete row of AD bristles; AV surface bare. Fore tibia without submedian setae. Hind femur with complete rows of bristles along AV and AD surface; 3 weak preapical PV setae. Hind tibia with $2 \mathrm{AV}$ setae in apical half; 1 median and 1 preapical AD setae. Abdomen. Ground colour yellowish on segments 1-3, blackish on 
posterior ones. Tergites $1+2,3,4$ and part of 5 with black bands along posterior margin. Tergites 3 to 5 with a median black stripe. Ovipositor (Figs 1,2).

Measurements. Length of body, 5,2mm. Length of wing, 4,4mm.

Material examined: BRASIL. Roraima: Alto Alegre (Ilha de Maracá), 1-4/III/88, J.A. Rafael, J.E.B. Brasil, L.S. Aquino leg, 1 female (DZUP).

Remarks. This species was collected using decomposing organic matter as bait in a Shannon trap, and was identified as Potamia sp. in CARVALHO \& COURI (1991:38). We have also seen 2 male [DZUP] of Micropotamia cilitibia (Albuquerque, 1955) from Rio Grande do Sul, collected in a Malaise trap.

ACKNOWLEDGMENTS. This paper was written at The Natural History Museum, London, with support from "Conselho Nacional de Desenvolvimento Científico e Tecnológico" (CNPq), and The British Council. For information on types in their care, I am grateful to M.S. Couri (MNRJ), J.A. Rafael (INPA) and to D.S. Amorim (Universidade São Paulo, Ribeirão Preto), and M.S. Couri for critical reading. I am also very grateful to Adrian C. Pont [Hope Entomological Collection, Oxford] for his valuable comments and suggestions during the preparation of this paper and for revising the English languague. This paper is offered in homage to Prof. Dr. Pe. Jesus Santiago Moure, founder of the Departament of Zoology at the Universidade Federal do Paraná, on the occasion of his $80^{\text {th }}$ birthday.

\section{BIBLIOGRAPHIC REFERENCES}

ALBUQUERQUE, D. DE O. 1955. Fauna do Distrito Federal: XXXV. Três novas espécies de Phaoninae (Diptera-Muscidae). An. Acad. bras. Cienc. 27 (3): $373-380$.

ALBUQUERQUE, D. DE O. \& S.M.R. LOPES. 1982. Sobre duas espécies novas de Muscidae da Amazônia pertencentes às subfamílias Muscinae e Cyrtoneurininae. Bolm Mus. Para. Emilio Goeldi, Ser. Zool. 117: 8p.

CARVAlHO, C.J.B. DE. 1981. Dendrophaonia plumata, sp.n. e Phaonia giacomeli, sp.n. da região Neotropical (Diptera, Muscidae). Revta bras. Ent. 25 (2): 141-144.

. 1983. Considerações sobre Phaonia Robineau-Desvoidy (Diptera, Muscidae) e descrição de novas espécies da região neotropical. Revta bras. Ent. 27 (3/4): 243-257.

.1989a. Revisão das espécies e posição sistemática de Palpibracus Rondani (Diptera, Muscidae). Revta bras. Zool. 6 (2): 325-376.

. 1989b. Classificação de Muscidae (Diptera): uma proposta através da análise cladística. Revta bras. Zool. 6 (4): 627-648.

— 1993. Dolichophaonia, gen.n. (Diptera, Muscidae, Phaoniinae): descrições, novas combinações, sinonímias e chave para as espécies. Revta bras. Ent. 37 (1): 19-34.

CARVALHO, C.J.B. DE \& M.S. COURI. 1991. Muscidae, Fanniidae e Calliphoridae (Diptera) do Projeto Maracá, Roraima, Brasil. Acta Amazonica 21: 35-43. 
FAN, Z. 1992. Key to the common flies of China. $2^{\text {a }}$ ed. Beijing, 992p. HENNIG, W. 1965. Vorarbeiten zu einem phylogenetischen System der Muscidae (Diptera: Cyclorrhapha). Stuttg. Beitr. Naturk. 141: 100p.

HUCKETT, H.C. 1965. Muscidae, p. 869-915.In: Stone, A.; C. W. Sabrosky; W.

W. Wirth; R. H. Foote \& J. Coulson (eds.). A Catalog of the Diptera of America North of Mexico. U. S. Dep. Agric. Agric. Handbook No. 276: IV +1696 .

HUCKETT, H.C \& J.R. VOCKETOTH. 1987. Muscidae, p. 1115-1131. In: MCALPINE, J.F.; B.V. PERTERSON; G.E. SHEWELL; H.J. TESKEY; J.R. VOCKEROTH \& D.M. WOOD (eds.). Manual of Nearctic Diptera 2: 675-1332, Monograph No. 28, Agriculture Canada Ottawa, p. 675-1332.

MCALPINE, J.R. 1989. Phylogeny and classification of the Muscomorpha, p. 1397-1518. In: MCALPINE, J.F. \& D.M. WOOD (eds.). Manual of Nearctic Diptera 3. Monograph No. 32, Agriculture Canada, Ottawa, p. 1333-1581.

MICHELSEN, V. 1978. Cryptophyra lundbecki, n.gen. et n.sp. from North Europe, with some notes on hydrotaeine genera (Diptera: Muscidae). Ent. scand. 9 (2): 85-92.

- 1991. Revision of the aberrant New world genus Coenosopsia (Diptera, Anthomyiidae), with a discussion of anthomyiid relationships. Syst. Entomol. 16: 85-105.

PONT, A.C. 1972. Family Muscidae. In: A Catalogue of the Diptera of the Americas South of the United States 97. São Paulo, Museu de Zoologia, Universidade de São Paulo, 111p. 1977. Family Muscidae, p. 451-523. In: DELFINADO, D. \& D.E. HARDY (eds.). A Catalogue of the Diptera of the Oriental Region. 3. Suborder Cyclorrhapha (excluding Division Aschiza). Honolulu, University of Hawaii Press, 854p.

- 1986. Family Muscidae, p. 57-215. In: A. SOÓS \& L. PAPP (eds.).

Catalogue of Palaearctic Diptera 11, Scathophagidae-Hypodermatidae. Budapest, 346p.

SHINONAGA, S. \& R. KANO. 1971. Muscidae (Insecta: Diptera), I. In: Fauna japonica 1. Tokyo, Academy Press of Japan, 242p.

SKIDMORE, P. 1985. The biology of Muscidae of the world. Series ent. 29: $550 \mathrm{p}$.

Recebido em 01.III.1993; aceito em 11.VIII.1993. 